\title{
The Influence of Airlines' Corporate Social Responsibility on Customer Loyalty
}

\author{
Ghada Khairat
}

\author{
Azza Maher
}

\section{Tourism Studies Department University of Sadat City}

\begin{abstract}
This paper aims at exploring the relationship between corporate social responsibility and customer loyalty in the airline industry. To achieve the purpose of this paper, a model has been developed to measure the influence of airlines' corporate social responsibility- activities on customer loyalty and airline image. This model includes 16 attributes, which have been selected to cover airlines' CSR activities, and 21 initial items for measuring customer loyalty. The sample chosen in this study includes mainly international airlines passengers (727 passengers). The results of this study show a significance statistical relationship between airlines' CSR activities and customer loyalty.
\end{abstract}

Keywords: Corporate social responsibility, Airline CSR initiatives, Customer loyalty, Airline social responsibility.

\section{Introduction}

A corporate social responsibility (CSR) strategy is a long- term plan developed in terms of specific activities and investments aligned with the organization to meet the requirements of customers, stakeholders, and the society as a whole. ${ }^{1,2}$ Corporations are increasingly adopting socially responsible actions, policies, and activities.

Furthermore, a corporate social responsibility (CSR) strategy is beneficial not only for the social, environmental, and financial performance of a corporation but also for its employees, stakeholders, customers, and communities. ${ }^{3}$ Besides, CSR programs help to attract and retain high- quality employees, improve employees' satisfaction, generate a positive corporate image, enhance product evaluation via an overall evaluation of the firm, and increase customer's willingness to purchase the products of the company. In fact, consumer purchase intention has been positively correlated with the degree to which the perceptions of a company's ethical behavior exceeded the customer's expectations. Generally, customers appear to provide greater support for companies that are socially and environmentally responsible. ${ }^{4}$ Also, this may help stakeholders make informed decisions about the sustainability of a company's operations. ${ }^{5}$

Moreover, corporate social responsibility (CSR) has received a considerable attention from the airline industry. The operations of airline companies have inevitable and substantial impacts on the environment and society. Thus, various stakeholders have mounted pressure on companies in the airline industry to undertake initiatives to reduce or mitigate the negative impacts of their operations. Consequently, airlines are increasingly implementing CSR policy initiatives.

In addition, companies aim to use corporate social responsibility (CSR) as a marketing tool to influence customer loyalty, which is one of the most essential consumers' behaviors. ${ }^{6}$

When an airline invests resources in activities related to social responsibility and considers such investment as a part of the promotion and marketing of the company, airline managers want to know the likely impact of such measures, especially those relating to customers' knowledge and opinions of CSR, and how that affects the relationship between customers and airlines. The objective of all CSR initiatives is to take responsibility for all the actions of the firm as well as to operate in a way that will positively impact the environment, communities, employees, customers, and all other relevant stakeholders. For airline companies, it is essential to meet their customers' growing demands in a sustainable manner and maintain the highest balance between economic development and social and environmental responsibility. ${ }^{6,7}$ The responsibility of corporations does not only include providing products and services; it must also take care of the welfare of the various 
stakeholders in society. Customers' expectations for firms to assume more social responsibilities are rising as well.

CSR may contribute efficiently to the formation of airlines' strategies. First, the flying of airplanes has negative effects on the global environment. Therefore, airlines can create a positive public image through caring about protecting the environment. Second, the airline industry witnesses a growing competition. Airlines offer similar products and services; hence, implementing CSR would be considered a distinguished element. Finally, international airlines cover a wide range of countries, and they are expected all the time to fulfill their responsibilities as a corporate citizen in order to meet the expectations of many stakeholders and customers. Thus, airlines can benefit from the positive effect of applying CSR. ${ }^{8}$

Airline companies have increasingly demonstrated a number of social management practices and environmental responsibility. So far, a large number of firms have been stuck at the first stage of CSR integration into strategic thinking, that of pollution prevention. Some companies have moved to the second stage, which looks not only at pollution in general but also at the environmental impact of the full product life cycle. The third level looks at the development of the so-called clean technologies contributing to the solution of environmental and social challenges. These three stages forge a company to sustainability. A clear and fully integrated environmental strategy should not only guide competency development, but also shape the company's relationship with customers, suppliers, other companies, policy-makers, and all its stakeholders. ${ }^{\text {? }}$

There is currently little research addressing the influence of airlines' CSR practices on the passengers' loyalty. However, the airline industry is prominent with regard to applying CSR compared to other sectors. ${ }^{5,10}$ Therefore, this paper aims to explore the relationship between corporate social responsibility and customer loyalty in the airline industry.

\section{Literature Review}

\section{Corporate Social Responsibility (CSR) Definition}

Obviously, CSR has developed across the business community. An increasing number of companies consider businesses as being part of the society and perceive their important effect on the society. Corporate social responsibility is often recognized as corporate social performance, business ethics, corporate citizenship, and corporate social accountability. ${ }^{\mathbf{9} 11}$

Corporate social responsibility is defined by ${ }^{11}$ as "a company's commitment to minimizing or eliminating any harmful effects and maximizing its long run beneficial impact on society". Furthermore, ${ }^{12,13}$ define CSR as "the commitment of business to contribute to sustainable economic development, working with employees, their families, the local community and society at large to improve their quality of life". More comprehensively, it is describe CSR as "various dimensions including economic development, ethical practices, environmental protection, stakeholders involvement, transparency, accountability, responsible behavior, moral obligation, corporate responsiveness and corporate social responsibility, human rights, law abidance, quality improvement, community investment, workplace, and voluntariness"14,15. Similarly, define corporate social responsibility is "the continuing commitment by business to behave ethically and contribute to economic development while improving the quality of life of the workforce and their families as well as of the local community and society at large"16,17 . CSR also refers to "a company's activities and status related to its perceived societal or stakeholder obligations"18 as well as "the extent to which a firm benefits and contributes to society in positive ways". ${ }^{19}$

Moreover, according to ${ }^{\mathbf{2 0}}$ economic, legal, ethical and philanthropic responsibilities are the major elements of corporate social responsibilities; they are also known as the Carroll's CSR pyramid. Carroll's pyramid of CSR is one of the most used and quoted models. ${ }^{21}$ The economic responsibility refers to the firm's obligations to be productive, profitable, and to maintain wealth. The legal responsibility refers to carrying out activities within the confines of legal requirements. The ethical responsibility refers to having ethical codes, norms, and values going beyond mere legal frameworks; it also refers to companies being honest in their relationships with their customers and their own employees and doing what is right, just, and fair to avoid harms. The philanthropic responsibility includes voluntary work or activities and donations aiming to raise the well-being and development of society as a whole. ${ }^{\mathbf{8 , 2 2 , 2 3 , 2 4}}$ 
Moreover, this four-element concept helps business organizations to understand the CSR philosophy and paves the way for beginners to be engaged in CSR activities effectively. ${ }^{\mathbf{2 4 , 2 5}}$ Therefore, socially responsible companies are expected to: (1) Be profitable while providing desired goods and services (fulfill their economic responsibility); (2) obey the law (fulfill their legal responsibility); (3) follow codes of conduct considered as morally right (meet their ethical responsibility); and (4) contribute actively to the well-being of the communities in which they operate (address their philanthropic responsibility). ${ }^{\mathbf{2 6}}$

On the other hand, different CSR actions are summerized ${ }^{\mathbf{1 8 2 3}}$ into five broad domains: (1) Community support (arts, education, corporate giving, charitable giving, innovative giving, volunteer programs, and housing); (2) diversity (sex, race, disability, promotion of women or minority employees, contracting with women and minority suppliers, (3) employee support (job security, the provision of retirement benefits, favorable union relations, and ensuring of employees' health and safety); (4) environment (environmentallyfriendly products, use of clean energy, sustainable management systems, waste management, and pollution control); and finally (5) product quality (safety, innovative products, and proxy for consumer relations).

CSR general principles also include a number of elements. First, companies' goal is to achieve profit. Second, companies have to work on improving their image through setting right the negative effects they have on the society. Third, the main responsibilities of managers are to consider customers, shareholders, and employees; however, less priority is given to communities and governments. ${ }^{27}$

\section{CSR B enefits}

For a company, many benefits result from applying a CSR strategy. Such benefits could be of more or less importance due to the overall business actions and the markets where the company exists. These benefits include: ${ }^{9,28,29,30,31}$

First, improving financial performance: Many academic studies have revealed a relationship between CSR and improved financial performance. CSR is concerned with seizing the opportunity and avoiding risk through making use of innovations, competitiveness, and market positioning. Moreover, a company can generate ideas for new products based on feedback from different stakeholders; this may grant it a competitive advantage in the market.

Second, reducing operating costs: The improved operational efficiency through a systematic approach to management that includes continuous improvement is essential in reducing operating costs. It also includes environmentally oriented programs resulting in energy efficiency, reducing utility bills, and recycling to reduce waste disposal costs. In addition, human resources programs introduce work-life scenario reducing absenteeism and increasing retention; thus, reducing employee turnover costs.

Third, enhancing brand reputation: Companies that manage well with regard to CSR can build their reputation. Reputation is represented in trust, credibility, reliability, quality, and consistency.

Fourth, responsible consumerism and customer loyalty: Ethical conduct and environmental and social awareness of companies affect customers' purchasing decisions. The goods and services that companies provide and how they are provided are essential for facilitating sustainable consumption patterns and lifestyles.

Fifth, increasing productivity and quality: Improved working conditions are as important as involving employees in the decision-making processes. They increase productivity and reduce failures.

Sixth, increasing ability to attract and retain employees: Strong CSR commitment eases the process of recruiting highly qualified employees, boosts morale, and brings about higher retention rates.

Seventh, improving relations with regulators: In a number of jurisdictions, governments accelerate approval processes for companies that have undertaken social and environmental activities beyond those required by regulation.

Finally, access to capital: Financial institutions are increasingly integrating social and environmental criteria into their assessment of projects and in their decision- making process. Hence, effective CSR management might give a company the competitive edge that is needed to convince the financial institutions to invest into their business.

\section{CSR Activities in the Airline Industry}


Nowadays, it is crucial for companies to have a business strategy since forecasting, measuring, and developing business actions are highly required in business life. Also, there will always be competitors that are potentially doing better business regarding overall revenues which consequently leads to a need of efficient and structured operations to ensure long- lasting business success. Businesses that are going to last and also be profitable in the future are the ones with CSR incorporated into their business strategy. CSR allows the company to be successful whilst using its resources within its unique environment to meet market needs as well as to meet stakeholders' expectations. ${ }^{32}$

Airlines are committed to conducting their business in a responsible and transparent manner, striving to serve the society and community as well as to manage their social and environmental footprints. It is important that airlines approach and activities make sense for both business and society. Thus, the key areas of airlines CSR activities are as follows: ${ }^{33}$

1. Business operations: Including health and safety, environment, and compliance management.

2. Workplace: Including employees' satisfaction and well-being, education, and workforce development.

3. Community: Including charities contributions, sponsorships, donations, and stakeholder engagement.

4. Customer: Including high- quality products, being honest with customers, raising awareness of sustainability issues, value for money, and offering loyalty programs.

\section{Business Operations}

\section{(A) Health and Safe ty}

Safety is one of the most important areas of the airline business, concerning customers as well as employees. Therefore, various systems should be implemented to support safe business operations. In order to ensure work safety, training supported by risk management systems should be implemented. Key performances should be regularly measured and improved according to the legal requirements by internal and external auditors. Furthermore, most airlines have risk management systems which give employe es the opportunity to report mistakes, risks, and near misses. ${ }^{32}$

\section{(B) Environment}

Due to the current nature of the market environment in which airlines operate, environmental issues should be considered the most important ones. Despite the fact that airlines contribute only a few percent to global $\mathrm{CO} 2$ emissions, many people consider flying to be much more harmful than driving a car, for an equal number of kilometers.

Therefore, airlines are pressured into contributing to the environment and reducing their environmental impact. It has become apparent that by focusing on environmental issues companies can gain a competitive edge through improved image and operational efficiency. The most important environmental issues that need to be addressed by airlines are fuel efficiency, waste and recycling, carbon off-setting schemes, reduction of hazardous materials, and supporting environmental projects. ${ }^{32}$

\section{(C) Compliance Management}

Compliance management refers to the company's work to make sure that the outcome of the activities in operations and maintenance meet the regulatory, customer, and company requirements. The quality policy is the underlying principle of the compliance management. It is realized by the compliance management organization, the documented operational and technical procedures, the training arrangements for all employees, and the independent quality assurance process. ${ }^{33}$

\section{Workplace}

If there is a good employee relation, this positively affects organizations functioning, resulting in lower turnover rate, higher productivity, motivation, and loyalty. ${ }^{3}$ Therefore, airlines strive for a workplace that motivates, engages, supports, and develops employees. The commitment of all staff members to corporate responsibility is considered to be the main goal. In order to achieve a better working environment, the main focus areas should deal with responsible colleagues, improving tools to do the jobs, investing in human resources through improved training ${ }^{34}$, career development possibilities, personal development, proper worklife balance, ensuring equal opportunities and treatments, integration, and non-discrimination. Focusing on employment issues is important due to the high contribution of business staff to the overall business process. 
Thus, due to the expense of hiring and training completely new employees, airlines should try to retain and develop the existing workforce. ${ }^{9,32,35}$ Several airlines also promote programs that encourage diversity and equal opportunities. Although most such programs (i.e. hiring disabled persons, minorities, and elderly) are required by law, some companies make better efforts to help women and minority to advance in their careers. Such actions are necessary to ensure a positive, modern, and tolerant workplace. ${ }^{32}$

Moreover, airlines emphasize that safety and people are at the core of their organizational culture, and they continually strive to provide a safe and harmonious work environment, career progress, fair wages, cash profit sharing, flexible working hours, and retirement benefits. ${ }^{8}$ It is logical that an employee who is satisfied with his/her job and feels fairly treated will also be a more energetic, creative, and productive employee. ${ }^{32}$ Accordingly, airlines focus on employees' satisfaction and well-being, knowing that satisfied and motivated employees are more productive and efficient. ${ }^{33}$ The nature of the airline industry makes it a challenge to nurture employees since airlines have to do their best to keep costs down in order to compete in the market. The main challenges facing airlines can be health and safety, recruiting and retaining qualified employees, and maintaining employees' satisfaction to ensure the long-term sustainability of workforce. ${ }^{\mathbf{8}, 32}$

Furthermore, women are considered to be an important factor in the workplace today. Consequently, companies seek developing programs and policies to make work and the workplace more family-friendly. Companies provide or facilitate to employees day care centers and kindergartens. Also, more flexible parental leave policies are being developed. In addition to these policies and practices, some leading companies acknowledge that changing work practices, work structure, and work culture in order to improve work-family integration can lead to increased productivity, employee commitment, innovation, lower turnover, and better quality. In other words, work-family integration can be recognized as a competitive advantage. ${ }^{36}$

\section{Community}

Because airlines have a high impact on neighborhoods and communities surrounding their major hubs, it is the responsibility of airlines to support these communities. Airlines support communities by recruiting and training local staff, buying supplies and services from local businesses, offering educational support to local institutions, ${ }^{32}$ supporting various charities contributions, sponsoring projects, contributing to infrastructure. ${ }^{9,3}$, participating in volunteer programs ${ }^{23}$, being involved in sports and cultural events through sponsorships, offering charity donations, sponsoring social crises, and providing other supportive actions. In addition to supporting local communities, several airlines as well as their employees are actively involved with international charities to support impoverished communities. Such charities normally deal with health care, human rights, and education. ${ }^{32,37}$

Moreover, being attentive to stakeholder concerns is a key component of the airlines' corporate social responsibility strategy. ${ }^{38}$ A stakeholder is defined as "any group or individual who can affect or is affected by the achievement of the firms' objectives". ${ }^{37}$ Primary stakeholder groups consist of shareholders and investors, employees, customers, suppliers, unions, public entities, such as governments or other public organizations that set laws and govern economic commerce, non-governmental organizations, trade associations, and environmental groups. ${ }^{4,39}$

Stakeholder engagement is a strategy to keep in touch with relevant stakeholders. It is based on understanding and considering stakeholders' views, being accountable to them, and using the information acquired from them to improve the business. Three main reasons for adopting stakeholder engagement are:

Building social capital, reducing risk, and fuelling innovation through increased stakeholder interaction and communication.

Furthermore, suppliers are often encouraged to commit to the responsibility plan of an airline. Because airlines have negotiation power, suppliers have to adapt changes in the business, such as sustainability. In order to ensure responsible procurement, products, and services that lead to customer satisfaction, suppliers have to move their business practices toward sustainability. Airlines require their suppliers to abide by CSR principles and meet ethical and practice standards throughout the procurement and supply chain management processes. $^{32}$ 


\section{Customer}

Excellent customer experience is the essence of success in big companies. Satisfied customers are willing to continue dealing with the company. ${ }^{31}$ Successful companies build long- lasting relationships with their customers through understanding their needs and providing them with best quality, services, and reliability. ${ }^{36}$ Thus, airlines are striving toward exemplary customer relations by proving a level of customer service and comfort that ensure customer loyalty, focusing on safety and security, meeting customer expectations, involving customers with the CSR program, and raising passenger awareness of sustainability issues. ${ }^{40}$

Airlines offer services that save customers' time and affect their experience positively. Airlines are mainly interested in building a long- term relationship with customers to ensure repeat patronage. Therefore, most airlines establish and maintain frequent flyer databases to develop customers' profiles in order to provide customized products and services and create superior customer value, which in turn would lead to customer satisfaction. Airline uses the frequent flyer program (FFP), which is one of the relationship marketing strategies, to build customer loyalty. An FFP involves incentive packages designed to encourage loyal passengers' patronage and reward them according to the distance flown on the airline. ${ }^{41}$ Furthermore, other customer services include offering healthy meals or providing special services, such as helping disabled passengers or unaccompanied youth. ${ }^{32}$

In a successful relationship marketing strategy, there is a mutual benefit relationship between both customers and airlines. Customers can benefit from this relationship only if they want to engage in long-term relationships. For airlines, establishing a strong customer relationship ensures customer loyalty, which in turn increases company's profits. ${ }^{41}$

\subsection{Challenges of Practicing CSR}

The most important challenges of practicing CSR are summarized as follows: ${ }^{42}$

First, educating employees, customers, and other stakeholders: For many, CSR is a new concept. Aiming for everyone to understand and support CSR in the organization is a key challenge.

Second, deciding a focus and choosing priorities: CSR can mean many different things. Each organization needs to make sense of CSR for itself, choosing its own focus and priorities. Moreover, figuring out how to incorporate and align different practices cooperatively across people in the organization can be immensely challenging. This can be achieved through considering the processes or practices that could be developed to improve the social responsibility of the particular business, the changes required to develop these processes, and taking into consideration the unmanageable or not viable practices.

Third, proving the business case for CSR: Some small and medium size enterprises (SMEs) find it difficult to clarify the business advantages of CSR to all stakeholders.

Fourth, high implementation costs of CSR: Elevated expenditures may include "green" products and practices, community donations and services, employee development and employee earnings allocated to allow their involvement in community connection activities, and possibly higher costs for local products and services. These costs are tough for some businesses, particularly SMEs and those struggling against low price points set by retail giant competitors.

Fifth, tracking implementation, business performance, and progress in CSR: This can be done through studying the most valid indicators, the outcomes to be measured, and the measures making the most sense to different stakeholders.

Sixth, no supporting government regulation: Most companies see themselves as more progressive than the government. There is a need for the government to adopt as a first step the sustainable practices itself, screen its purchases for the social and environmental practices of suppliers, and support CSR companies by using them as suppliers of choice. There is also a lack of financial support in terms of tax incentives for responsible practices and subsidies for buying responsible products/services to offset the high proportional cost. 
Seventh, special challenges of rural or remote-area firms: These firms may lack access to environmentally friendly suppliers and products, have fewer supporters, and need to educate their own communities about the value of CSR and its higher prices.

\subsection{Corporate Social Responsibility and Customer Loyalty}

Customer loyalty is considered a vital aim for a company's survival and growth. Actually, building a loyal customer base has not only become a major marketing goal but it is also an important basis for developing a sustainable competitive advantage. Obviously, the success of a brand in the long term is not based on the number of customers that buy it once but on the customers who require the service repetitively. ${ }^{43}$

Customer loyalty is defined as the relationship of relative attitudes the object (brand, service, and provider) and repeat patronage. Moreover, customer loyalty has three aspects: A cognitive aspect associated with informational determinants; an affective aspect associated with emotion toward the brand; and a conative aspect associated with behavioral intention toward the brand.

The concept of customer loyalty refers to a mix of positive attitudes that lead to repurchase intentions, recommending good or service to others, and willingness to pay more. It is commonly recognized that customer satisfaction is the base for customer loyalty, which in turn affects profitability. ${ }^{22,44,45}$

Customer loyalty definitions can be grouped into two categories ${ }^{4}$ : Process and psychological. On the one hand, process or operational definitions are concerned with customers' behavior to show loyalty; and it is reflected in repeat purchasing or relative volume of same-brand purchasing. On the other hand, psychological or theoretical definitions concentrate more on the customer's deep-seated commitment or internal tendency to continue purchasing from the same brand. This perspective includes both the attitudinal and behavioral measures of loyalty and expresses the loyalty concept more comprehensively as: "a deeply held commitment to rebuy a preferred product/service consistently in the future, thereby causing repetitive same-brand or same brand-set purchasing, despite the situational influences and marketing efforts having the potential to cause switching behavior." ${ }^{46}$ Also, customer loyalty is an important concept for corporations. It refers to the customers' tendency and intention to repeat buying products and services from a firm thus reflecting their positive image of that firm. In general terms, it refers to attitudes toward a company and resultant patronage behavior. Moreover, customer loyalty can manifest itself through one or a combination of five dimensions, which are also called antecedents or consequences of loyalty: Attitudinal, behavioral, situational, personality traits, and resistance to competing offers. ${ }^{7,47,48}$ In addition, customers are no longer just satisfied with the products. They also consider the company's behaviors when making their purchase decision. For instance, environmentally concerned companies are always recognized as good-reputation or community business. $^{45}$

Clarified ${ }^{4}$ that CSR initiatives in various forms become active channels for building customer loyalty. For example, supporting a cause, employee diversity, charitable giving, community involvement, supporting women's rights, and philanthropy all have been shown to assist in generating loyal customers because customers realize the positive difference companies make in communities supported by the positive moral attitude taken by the firms. ${ }^{49}$ For companies with high perceived CSR, their customers will have a stronger trust-loyalty link. ${ }^{45}$ More broadly, customers appear to provide greater support for companies that are socially and environmentally responsible. ${ }^{4}$

\section{Methodology}

\section{Research Design}

The study uses an exploratory survey to elicit attitudes and perceptions of customers (passengers) to airlines' corporate social responsibility. The survey is designed to describe population characteristics, knowledge, beliefs, attitudes, preferences, and behaviors. It is worth mentioning that similar studies have successfully employed survey design. $\mathbf{1 4 , 5 0}^{-1}$

To achieve the purpose of this paper, a model has been developed to measure the influence of airlines' corporate social responsibility activities on customer loyalty and airline image. 


\subsubsection{Item Generation and Creating Model}

A research model has been developed through investigating a number of literature studies related to the objectives of this research considering the relationship between CSR and loyalty. ${ }^{51,52}$ ( as shown in Figure 1).

To generate initial items, an extensive review of literature has been conducted in the broad contexts of airlines' corporate social responsibility $\mathbf{5 , 6 . 7 , 8 , 1 7 . 2 8 , 4 7}$, service and customer equity ${ }^{\mathbf{5 3 , 5 4}, \mathbf{5 5 , 5 6 , 5 7}, \mathbf{5 8}, \mathbf{5 9}}$, brand equity $^{60,61,62,63,64,65,66,67}$, value equity ${ }^{68,69,70,71,72,73,74,75}$, loyalty ${ }^{76}$, relationship management ${ }^{77}$, and marketing management ${ }^{78,79,80,81,82,83}$.

The conclusion from the review of literature acts as a guide to develop and empirically test the model that shows the relationships among CSR activities. If customers are aware of CSR activities that airlines have implemented, that will enhance their belief about company ability in doing their business and influence the airline image.

Through the above process, 21 initial items have been generated in attempting to cover airlines' CSR activities, including 8 items supporting business operations, 4 items for work place, 5 items regarding Community, and 4 items supporting customer attributes. Also, there are 29 initial items for measuring customer loyalty, including 11 items measuring airline image, 10 items supporting behavior intention, and 8 items for perceived value.

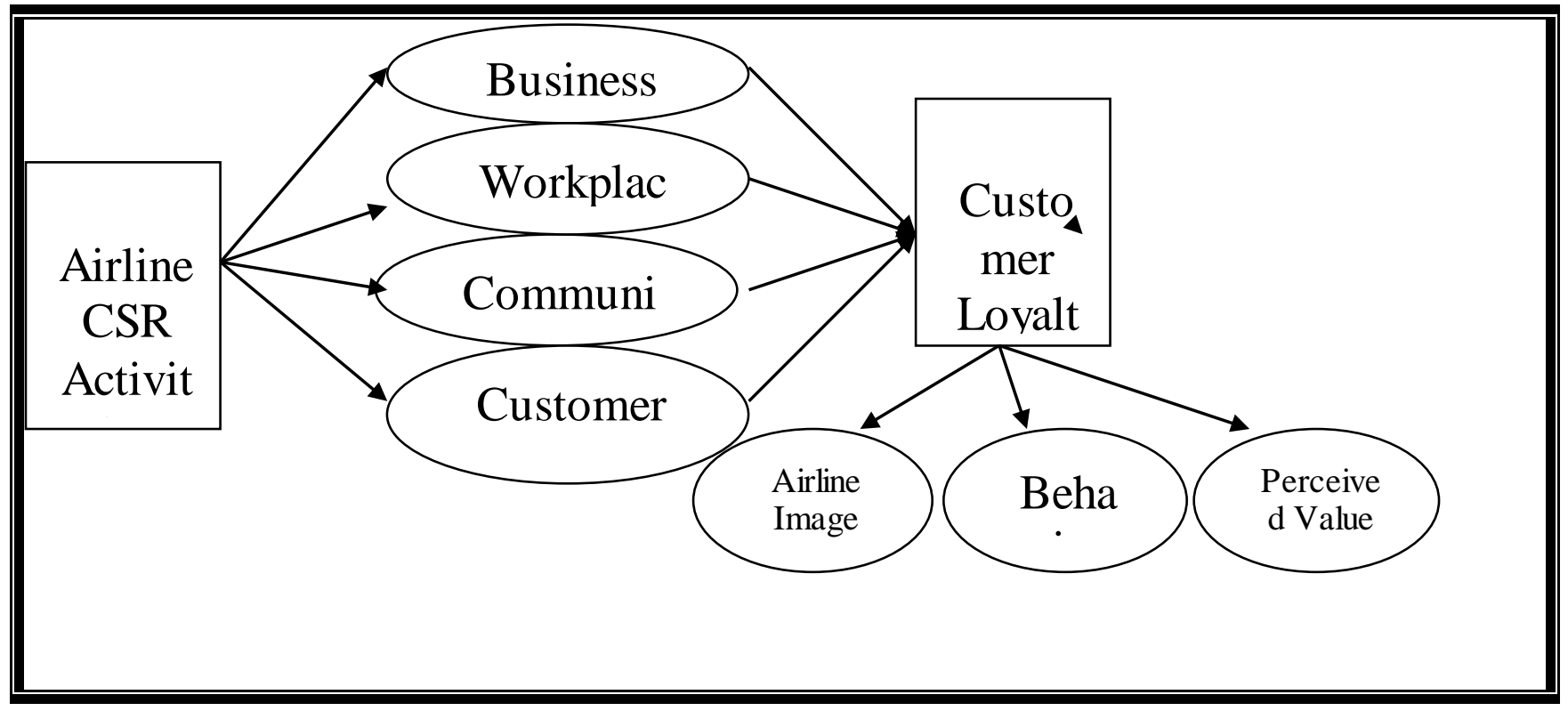

Figure 1 : A Conceptual Model Framework for Field Study

In the first stage, items that are not relevant to the travel industry or to the concept of customer loyalty have been deleted, based on the definitions of each dimension as well as the researchers' own understanding of the content area. Furthermore, to increase credibility, the collected items are identified and categorized by the two researchers. For judging the reliability of the sub drivers and items classification, kappa statistics have been calculated to measure the agreement between the two raters. ${ }^{84}$

The equation for $\kappa$ is:

$$
\kappa=\frac{\operatorname{Pr}(a)-\operatorname{Pr}(e)}{1-\operatorname{Pr}(e)},
$$

Where $\operatorname{Pr}(a)$ is the relative observed agreement among raters, and $\operatorname{Pr}(\mathrm{e})$ is the hypothetical probability of chance agreement, using the observed data to calculate the probabilities of each observer randomly saying each category. If the raters are in complete agreement then $\kappa=1$. On the other hand, if there is no agreement 
among the raters (other than what would be expected by chance), then $\kappa$ group $\leq 0 .{ }^{85}$ The classifications of the collected items is compared by an inter rater reliability analysis using the kappa statistics which is performed to determine consistency among researchers. The inter- rater reliability for the raters is found to be Kappa $=0.79$.

In the second stage, the list of initial items has been sent to three identified groups for comments. The three identified groups are: Academic staff, 4 managers in airline companies, and 5 potential travelers who were to leave Cairo Airport. Members of the three groups have been asked to rate each of the attributes in terms of importance to describe CSR and customer loyalty on a 5-point Likert scale, ranging from extremely important to extremely unimportant. After a careful screening analysis and advice from academic professionals, 16 of the 21 attributes have been selected to cover airlines CSR activities, and 21 of the 29 initial items have been selected for measuring customer loyalty (See Table 3).

\section{Data Collection}

\section{Research Instrument}

Structured questionnaires are used and administered. The proposed model has been presented as a selfadministrated questionnaire. This questionnaire consists of two sections: The first section is designed to elicit demographic information about the respondents. The second section consists of 37 items or statements to measure the relationship between airlines' CSR and customer loyalty. All collected items have been assessed on five-point Likert-type scales, ranging from 1 ('strongly disagree') to 5 ('strongly agree'). The initial questionnaire has been prepared and a pre-test has been conducted and presented to a number of samples $(\mathrm{N}=15)$ of international passengers who have recent experience of international travel.

The questionnaire re-probe coefficient is equal to 88.03. This constant verified the reliability of the questionnaire.

\section{Target Population and Sampling}

The population of the study comprises individuals who have a travel experience through airlines. Therefore, the data for this research are mainly obtained from a sample of flight passengers.

Population elements are selected on the basis of two criteria: (1) Individuals who regularly arrange their travel trips through international air- ways as these airlines are thought to offer CSR activities, compared to other airlines; and (2) passengers aged 18 and over. Passengers under 18 years of age are excluded from the sample because it is assumed that they would not have sufficient travel experiences to respond to all the questions in the questionnaire.

Data have been collected using the purposive sampling method since the purposive sample is appropriate to be used for specific criteria. ${ }^{86}$ In other words; this sample is preferred to be used if the characteristics of individuals are used as the basis of the selection. ${ }^{87}$

The power of purposive sampling lies in selecting information rich-cases for in-depth analysis related to the central issues being studied. Moreover, purposive sampling can be used with both quantitative and qualitative studies. ${ }^{\mathbf{8 8 , 8 9 , 9 0}}$

The sample chosen in this study includes mainly international airlines' passengers. Since the population is infinite, the sample size acceptable will be at least 384 units $^{91}$. The survey has been conducted at Cairo International Airport. A schedule of international airlines arrival and departures is studied. Also, the most important 3 to 4 days a week are assigned to conduct the survey. Table (1) presents the elements of the actual sample with regard to the airlines. 
Table 1 Elements of the Actual Sample

\begin{tabular}{|l|l|l|l|}
\hline Airlines & $\begin{array}{l}\text { Distributed } \\
\text { questionnaires }\end{array}$ & $\begin{array}{l}\text { Valid } \\
\text { questionnaires }\end{array}$ & $\%$ \\
\hline Air France & 96 & 88 & 91.6 \\
\hline Alitalia & 99 & 89 & 89.8 \\
\hline British Airways & 175 & 102 & 58.2 \\
\hline Iberia Airlines & 95 & 81 & 85 \\
\hline Singapore Airlines & 89 & 58 & 65.2 \\
\hline Lufthansa Airlines & 98 & 72 & 73.5 \\
\hline Emirates Airlines & 75 & 38 & 51 \\
\hline \hline Total & 727 & 582 & 72.6 \\
\hline
\end{tabular}

The self-report questionnaire has been distributed to a purposive selected group of 727 passengers of 7 international airlines. From the 727 questionnaires distributed, 592 responses are collected (for a response rate of $81 \%$ ). To avert the response bias, the data has been screened. After eliminating those with missing information and extreme answers, 582 usable responses have remained (usable response rate of $72.6 \%$ ).

\section{Data Analys is}

Data analysis is based on the use of descriptive and inferential statistics. Also, descriptive statistics including simple frequencies have been computed on the respondents' demographic and traveling profiles; and the mean model attributes are calculated. In addition, simple linear regression has been applied; this test tries to model the relationship between two variables by fitting a linear equation to observed data. One variable is considered to be an explanatory variable (such as CSR activities), and the other variable is considered to be a dependent variable (customer loyalty).

Moreover, a relationship between the variables of interest should be recognized before trying to fit a linear model to the observed data. Therefore, Spearman's correlation coefficient is used as a statistical measure of the strength of a monotonic relationship between paired data.

\section{Results and Discussion}

\section{Sample Characteristics}

A total of 582 out of 727 travelers completed the questionnaire in the 32-day survey period (12 March to 13 May, 2013) representing a response rate of $72.6 \%$. The table(2) shows the demographic characteristics of the respondents. The majority of the respondents interviewed are males (76\%); more than $75 \%$ of them are of 21 to 49 years old. With regard to the education level, the results show that the majority have attended College/University. More than half of the respondents have income level of form 50.000 to 69.000 US \$. 
The Influence of Airlines' Corporate Social Responsibility on Customer Loyalty

Table 2 Demographic Characteristics of the Respondents

\begin{tabular}{|c|c|c|}
\hline Attributes & Sample number & Frequency $(\%)$ \\
\hline \multicolumn{3}{|l|}{ Gender } \\
\hline Male & 443 & 76 \\
\hline Female & 139 & 24 \\
\hline \multicolumn{3}{|l|}{ Age } \\
\hline Under 20 years & 101 & 17.4 \\
\hline From 21- 49 years & 438 & 75.3 \\
\hline Over 50 years & 43 & 7.3 \\
\hline \multicolumn{3}{|l|}{ Educational level } \\
\hline Primary & 5 & 1 \\
\hline Secondary/High School & 198 & 34 \\
\hline College/University & 362 & 62 \\
\hline Postgraduate Degree & 17 & 3 \\
\hline \multicolumn{3}{|l|}{ Annual income (US \$) } \\
\hline Less than 10.000 & 55 & 10 \\
\hline $10.000-29.000$ & 45 & 7 \\
\hline $30.000-49.000$ & 53 & 9 \\
\hline $50.000-69.000$ & 295 & 51 \\
\hline $70.000-100.000$ & 134 & 23 \\
\hline \multicolumn{3}{|l|}{ Country of residence } \\
\hline Europe & 314 & 54 \\
\hline America & 78 & 13 \\
\hline Asia/Pacific & 87 & 15 \\
\hline Other nationalities & 103 & 18 \\
\hline \multicolumn{3}{|l|}{ Profession } \\
\hline Management/Administrative & 207 & 36 \\
\hline Professional & 124 & 21 \\
\hline
\end{tabular}




\begin{tabular}{|l|l|l|}
\hline White collar worker & 78 & 13 \\
\hline Blue collar worker & 28 & 5 \\
\hline Self-employed & 114 & 20 \\
\hline Retired & 19 & 3 \\
\hline Others & 12 & 2 \\
\hline
\end{tabular}

Table (2) illustrates that $54 \%$ of the respondents reside in Europe, while only $28 \%$ of them are from America and Asia/Pacific. The profession of the respondents seem to be evenly distributed between the three groups Management/Administrative, Professional, and Self-employed.

Table 3 Mean Rating and Factor Loading of Airlines' CSR Activities and Customer Loyalty Attributes

\begin{tabular}{|c|c|c|c|}
\hline Attributes & Mean & $\begin{array}{l}\text { Standard } \\
\text { de viation }\end{array}$ & $\begin{array}{l}\text { Factor } \\
\text { loading }\end{array}$ \\
\hline 1-Airlines' CSR activities. & 3.02 & .53 & \\
\hline a- Business ope rations & 2.9 & .71 & - \\
\hline - Airline provides a safe and reliable transportation service. & 3.2 & .98 & 0.743 \\
\hline $\begin{array}{l}\text { - Airline provides a safe working and business environment } \\
\text { to ensure the safety of its employees and customers. }\end{array}$ & 3.5 & .59 & 0.727 \\
\hline $\begin{array}{l}\text { - Airline provides a clearand effective complaints program } \\
\text { for customers to solve their problems fairly and } \\
\text { immediately. }\end{array}$ & 3.0 & .82 & 0.704 \\
\hline $\begin{array}{l}\text { - Airline uses renewable energy and reduces on-ground } \\
\text { energy consumption. }\end{array}$ & 2.6 & .47 & 0.652 \\
\hline $\begin{array}{l}\text { - Airline lowers the pollution caused by its business } \\
\text { activities. }\end{array}$ & 2.6 & 1.2 & 0.867 \\
\hline $\begin{array}{l}\text { - Airline carries out its business activities in accordance } \\
\text { with the environmental regulations and policies } \\
\text { stipulated by governments and international covenants. }\end{array}$ & 2.9 & .82 & 0.858 \\
\hline $\begin{array}{l}\text { - Airline volunteers the services of rescuing, transportation, } \\
\text { and supply in times of disaster. }\end{array}$ & 2.6 & .95 & 0.835 \\
\hline b- Work place & 2.8 & .83 & - \\
\hline $\begin{array}{l}\text { - Airline encourages its employees to participate in } \\
\text { volunteer services. }\end{array}$ & 2.7 & .45 & 0.568 \\
\hline
\end{tabular}


The Influence of Airlines' Corporate Social Responsibility on Customer Loyalty

\begin{tabular}{|c|c|c|c|}
\hline $\begin{array}{l}\text { - Airline engages its employees in its personal } \\
\text { responsibilities. }\end{array}$ & 2.9 & .85 & 0.696 \\
\hline c- Community & 3.1 & .75 & - \\
\hline - Airline pays attention to its influences on the society. & 3.2 & .98 & 0.670 \\
\hline $\begin{array}{l}\text { - Airline contributes to social welfare, such as voluntary } \\
\text { work support. }\end{array}$ & 3.5 & .94 & 0.539 \\
\hline - Airline provides continuity of leisure activities supply. & 3.5 & .79 & 0.863 \\
\hline $\begin{array}{l}\text { - Airline spends a fixed amount of profit on charity } \\
\text { Funding. }\end{array}$ & 2.6 & .49 & 0.834 \\
\hline d-Customer & 3.1 & .62 & - \\
\hline $\begin{array}{l}\text { - Airline respects customers' privacy and protects their } \\
\text { personal information. }\end{array}$ & 2.8 & .89 & 0.592 \\
\hline $\begin{array}{l}\text { - Airline's commercials or promotion do not deceive or } \\
\text { mislead customers. }\end{array}$ & 3.2 & .55 & 0.518 \\
\hline - Airline takes account of customers' interests and rights. & 3.2 & .79 & 0.719 \\
\hline 2-Customer loyalty & 2.9 & .5 & \\
\hline a- Airline image & 3.2 & .40 & - \\
\hline - I have always had a good impression of this airline. & 3 & .82 & 0.726 \\
\hline $\begin{array}{l}\text { - I believe that this airline has a better image than its } \\
\text { competitors. }\end{array}$ & 3.5 & .59 & 0.722 \\
\hline $\begin{array}{l}\text { - In my opinion, this airline has a good image in the minds } \\
\text { of passengers. }\end{array}$ & 3.5 & .78 & 0.719 \\
\hline $\begin{array}{l}\text { - The products and services of the airline are quality } \\
\text { assured and trust-worthy. }\end{array}$ & 3.0 & .21 & 0.594 \\
\hline - This airline has a good reputation in the travel industry. & 3.0 & .82 & 0.825 \\
\hline $\begin{array}{l}\text { - I often notice and pay attention to information or media } \\
\text { advertising of this airline. }\end{array}$ & 3.0 & .83 & 0.763 \\
\hline $\begin{array}{l}\text { - Some characteristics of the airline brand come to my mind } \\
\text { quickly. }\end{array}$ & 3.2 & .98 & 0.734 \\
\hline - $\quad$ The image of this airline fits my personality well. & 3.2 & .55 & 0.687 \\
\hline
\end{tabular}




\begin{tabular}{|c|c|c|c|}
\hline b-Behavior intention (Commitment) & 3.0 & .60 & - \\
\hline - You consider flying on this airline again in the future. & 3.2 & .59 & .934 \\
\hline - This airline is clearly the best brand in the market. & 2.9 & .82 & 0.579 \\
\hline - I recommend this airline to other people. & 2.9 & .79 & 0.766 \\
\hline $\begin{array}{l}\text { - I continue to travel with this airline because I genuinely } \\
\text { enjoy my relationship with them. }\end{array}$ & 3.1 & .96 & 0.594 \\
\hline - I feel emotionally attached to this travel agency. & 3.0 & .85 & 0.753 \\
\hline - My attitude toward this airline is extremely favorable. & 3.2 & .98 & .931 \\
\hline $\begin{array}{l}\text { - I always consider this airline to be the first one on my list } \\
\text { when searching for travel. }\end{array}$ & 2.6 & .90 & 0.578 \\
\hline - I have positive feelings toward this airline. & 3 & .82 & 0.786 \\
\hline $\begin{array}{l}\text { I would post positive messages about the company on } \\
\text { some Internet message board. }\end{array}$ & 3.2 & .55 & .998 \\
\hline c- Perceived value: & 2.5 & .55 & - \\
\hline $\begin{array}{l}\text { Compared to alternative companies, the company offers } \\
\text { attractive product/service costs. }\end{array}$ & 2.3 & .49 & 0.724 \\
\hline $\begin{array}{l}\text { - Compared to alternative companies, the company } \\
\text { charges me fairly for similar products/services. }\end{array}$ & 2.3 & .56 & 0.861 \\
\hline $\begin{array}{l}\text { Compared to alternative companies, the company provides } \\
\text { more free services. }\end{array}$ & 2.3 & .49 & 0.698 \\
\hline $\begin{array}{l}\text { - Comparing what I pay to what I might get from other } \\
\text { competitive companies, I think the company provides me } \\
\text { with good value. }\end{array}$ & 2.8 & 1.4 & 0.673 \\
\hline
\end{tabular}

\section{Factor Loading}

As shown in Table (2), the factor loadings of each item exceed 0.5, and so it meets the threshold level recommended by Bagozzi and $\mathrm{Yi}^{93}{ }^{93}$ The convergent validity of each scale's item is satisfying.

\section{Descriptive Results}

In order to measure CSR of airline passenger's perception, four corporate social performance dimensions have been selected. These dimensions are business operations, work-place, community, and customer.

According to Table (3) the mean scores on each dimension of CSR are 2.9 for business operations, 2.8 for work-place, and 3.1 for community and customer. These results shed light on the main areas of CSR that airlines concentrate on. Moreover, it is clear that the selected airlines for this study have greater efforts in the area of community and customer compared to other CSR activities. These results match the results of previous studies ${ }^{31}, \mathbf{3 6}, 41$ which have demonstrated that the main successful factor of any company is the customer. Also, some airlines ensure that being attentive to community activities is a key component of the airlines' corporate social responsibility strategy ${ }^{38}$. 
The results clearly reveal that the airline image and behavior intention are two powerful predictors of customer loyalty since airline image attributes have achieved a 3.2 with standard deviation .40 and behavior intention rating is 3.0 with standard deviation .60 .

The results in Table (3) also indicate that perceived value is another key driver of customer loyalty and also significantly influences customer loyalty, but only with rating mean 2.5.

The results of this study do not match with the findings suggested by ${ }^{\mathbf{9 4}}$ Yang and Peterson who have concluded that customer loyalty can be generated through improving customer satisfaction and offering high product/service value.

\section{Spe arman Correlation Analysis}

The spearman correlation has been applied into two stages: The first stage is to test whether there is any significant relationship between airlines' CSR activities and customer loyalty as a general base. The second stage is to examine the relationship between airlines' CSR activities and customer loyalty attributes. Customer loyalty is broken down into 3 main attributes, which are airline image, behavior intention, and perceived value. This stage has been carried out to discover which attributes have more contribution to or effect on the strength and direction of the relation.

Table 4 Spearman Correlation between Airlines' CSR Activities and Customer Loyalty Attributes

\begin{tabular}{|l|l|l|}
\hline Attributes & Correlation coefficient & Sig. \\
\hline Airline image & .893 & .000 \\
\hline Behavior intention & .699 & .000 \\
\hline Perceived value & .800 & .000 \\
\hline Customer loyalty & .734 & .000 \\
\hline
\end{tabular}

Note: Significance is at the $95 \%$ confidence level.

According to the results above, the value Spearman correlation coefficient between airline CSR activities and customer loyalty is .734; this indicates that there is a strong positive relationship between the two variables. Also, the results clearly reveal that the most effective attribute in this relation is "Airline image" since it has achieved .893 as a value of Spearman correlation. This means that promoting the airline image is strongly affected by airlines' CSR activities. These results confirm the study of Salmones et al. ${ }^{48}$ who have concluded that the CSR generates trust among users when evaluating the service that the firm provides to them.

\section{Simple Linear Regression Analysis}

As mentioned above, the main objective of this paper is to find out whether there is a linear relationship between airlines' CSR activities and customer loyalty. To achieve this goal Simple linear regression analysis has been used. Tables (5), (6), and (7) show the results of this analysis. 
Table 5 Statistical Characteristics of the Simple Linear Regression (Model Results ANOVA)

\begin{tabular}{|l|l|l|l|l|}
\hline Model & Sum of square & Mean square & F value & Sig. \\
\hline Regression & 10.149 & 10.149 & 1191.959 & .000 \\
Residual & .341 & .009 & & \\
Total & 10.490 & & & \\
\hline
\end{tabular}

Predictor: CSR activities

Dependent variable: Customer loyalty

Table 6 Model Summary

\begin{tabular}{|l|l|l|l|l|}
\hline Model & R & R square & $\begin{array}{l}\text { Adjusted } \\
\text { square }\end{array}$ & $\begin{array}{l}\text { Standard error of } \\
\text { the estimate }\end{array}$ \\
\hline 1 & .984 & .968 & .967 & .09228 \\
\hline
\end{tabular}

Table 7 Simple Linear Regression Coefficients

\begin{tabular}{|l|l|l|l|l|l|}
\hline Model & \multicolumn{2}{|l|}{$\begin{array}{l}\text { Unstandardized } \\
\text { coefficients }\end{array}$} & $\begin{array}{l}\text { Standardized } \\
\text { coefficients }\end{array}$ & T & Sig. \\
\cline { 2 - 5 } & B & $\begin{array}{l}\text { Std. } \\
\text { Error }\end{array}$ & Beta & \\
\hline CSR activities & .113 & .083 & .984 & .369 & .179 \\
& .930 & .027 & 34.525 & .000 \\
\hline
\end{tabular}

According to Table (5), there is a significant statistical relationship between airlines' CSR activities and customer loyalty $(\mathrm{f}=1191.959, \mathrm{P}<.005)$. The independent-mediator model, as indicated in Table (6), fits the data quite well, with an adjusted R2 of 0.96 , indicating that $96 \%$ of the variation in the dependent variable is explained by the equation.

If it is Supposed that $\mathrm{X}$-value is the observed values of the independent variable (CSR activities), while $\mathrm{Y}-$ value is the observed values of the dependent variable, which correspond to the respective $\mathrm{X}$-values, it can be concluded that the regression relation in the following formula is:

$$
\mathrm{Y}=.133+.930 \mathrm{X}
$$

According to the above tables, the simple linear regression model can be summarized in the following equation:

Customer loyalty $=.113+.930$ CSR activities.

It is clear that the main dependent variable (customer loyalty) is associated with CSR. This finding is in line with previous studies ${ }^{\mathbf{1 , 4 8 , 9 5 , 9 6 , 9 7}}$ which have concluded that the perception of socially responsible behavior has had a direct and positive influence on customer loyalty toward the firm. In addition, the results of this research also match with the study of Yuen ${ }^{45}$ who has stated that it is supported by evidence that companies with good CSR performance will gain more reputation. 


\section{Recommendations}

The study recommends that airline companies need to determine their sustainability policies and use corporate sustainability reporting standards. Besides, for developing corporate social responsibility marketing plans, a company should communicate intelligently its social orientation and its environmental involvement. Moreover, it is necessary for airlines to enrich their involvement in the community through promoting social projects, for example around education, culture or health, promoting volunteering, providing pro bono services or sponsoring social activities. They can use the internet and its web page in order to inform about its activities with a social dimension and create value to their products. Furthermore, the study suggests that special attention must be given to integrate social responsibilities with the airline 's strategic objectives. Finally, airlines need to implement CSR activities due to their role as a marketing tool, the marketers of airlines should develop new marketing strategies and try to benefit from corporate social responsibility in achieving effective marketing performance.

\section{Conclusion}

Corporate social responsibility (CSR) in airlines should be understood as a broad concept. It considers the philosophical and normative issues related to the role business plays in society. This study tries to shed more light on the concept of corporate social responsibility from the customer's perspective. Moreover, the research also shows its benefit as a tool to improve the image of an airline. First, corporate social responsibility does have an effect on customer loyalty but it only acts indirectly by means of service valuation. Hence, social responsibility becomes a clear marketing tool within the services market. Second, the results obtained in this research detect a certain relationship between corporate social responsibility and customer loyalty. Furthermore, the results clearly reveal that the most effective attribute in this relation is "Airline image"; this means that promoting the airline image is strongly affected by the airline's CSR activities. This research also shows that CSR activities could lead to customers' positive attitude towards the company. In this study, customer and community are the most important factors affecting the customer perceived airline image.

\section{Acknowledgements}

The assistance and co-operation of International Cairo Airport for permission to conduct the survey of this study is very much appreciated by the authors.

\section{References}

(1) Gigauri, I . (2012) Impact of Corporate Social Responsibility on Consumer Purchase Decision, Journal of Educational and Social Research , 2(9), 106-111.

(2) Barnes , A. (2011) Corporate Social Responsibility and its effects on Brand Trust, Master thesis, Auckland University of Technology.

(3) Kanji , G. and Chopra, P. (2010) Corporate social responsibility in a global economy, Total Quality Management, 21(2), 119-143.

(4) Pirsch, J. ; Gupta, S. and Grau, S. (2007) A Framework for Understanding Corporate Social Responsibility Programs as a Continuum: An Exploratory Study , Journal of Business Ethics , 70 , 125-140

(5) Smith, A.C. and Grosbois, D. (2011) The adoption of corporate social responsibility practices in the airline industry, Journal of Sustainable Tourism , 19 (1) , 59-77.

(6) Asatryan, R. (2013) The effect of CSR initiatives on customer loyalty in the airline industry, Mathematics and Computers in Contemporary Science . available at : www.studymode.com/essays/Csr-InViet-Nam-1845666.html [Accessed on19th June.2013] .

(7) Chen , F.; Chang ,Y. and Lin ,Y. (2012) Customer perceptions of airline social responsibility and its effect on loyalty , Journal of Air Transport Management , 20, 49-51.

(8) Chen, F. Y. and Lin, Y. S.(2009) Corporate Social Responsibility Initiatives of Major Asian Airlines , The 9th International Conference on Electronic Business, Macau, November 30 - December 4, Feng Chia University, Taichung, Taiwan. 
(9) Sloan, P. , Legrand, W. and Chen, J. (2009) Sustainability in the hospitality industry: Principle of Sustainable Operations , Butterworth-Heinemann , UK,P.118

(10) Tsai , W.H . and Hsu, J.L. (2008) Corporate social responsibility programs choice and costs assessment in the airline industry - A hybrid model , Journal of Air Transport Management, 14 (4),188- 196.

(11) Ali, I. ( 2011) Influence of Corporate Social Responsibility on Development of Corporate Reputation and Customer Purchase Intentions, Romanian Review of Social Sciences , 1, 19-27.

(12) World Business Council on Sustainable Development(2000) Corporate Social Responsibility: Making Good Business Sense. available at : /http:// www.wbcsd.org/includes/getTarget.asp?type=d\&id=MzE0S. [Accessed on 28 ${ }^{\text {th }}$ March.2013] .

(13) Özberk, B.; Güler, F. and Ata, E.U. (2011) Global Sourcing Strategies and CSR Implementation in Airline Industry, Master of Science In Industrial Engineering - Logistics Management, University College of Borås.

(14) Cheruiyot ,T. ; Maru, C. and. Muganda ,C.(2012) Reconstructing Dimensionality of Customer Corporate Social Responsibility and Customer Response Outcomes by Hotels in Kenya, Journal of business , Economics and Finance ,1(3) .

(15) Lee, S. and Park, S.Y.( 2010) Financial Impacts of Socially Responsible Activities on Airline Companies, Journal of Hospitality \& Tourism Research ,34 (2),185-203.

(16) Bernadette, S. ; Stephen, S. and Roshni, B.(2012) Corporate Social Responsibility : An Innovation to A Strategic Business Success- An Empirical Study, Maratha Mandir's Babasaheb Gawde Institute Of Management Studies. available at : /http:// www..docstoc.com- /.../ Corporate -Social -Responsibility -ANInnovati [Accessed on $20^{\text {th }}$ June2013]

(17) Lynes, J. and Andrachuk, M. (2008) Motivations for corporate social and environmental responsibility: A case study of Scandinavian Airlines, Journal of International Management, 14 , 377-390.

(18) Sen, S and Bhattacharya C. B. (2001) Does Doing Good Always Lead to Doing Better? Consumer Reactions to Corporate Social Responsibility, Journal of Marketing Research,38, 225-243.

(19) Yan , K. ( 2012 )The Impact of Corporate Social Responsibility on Customer Identification and Satisfaction: The Role of Personal Value, PhD thesis , Hong Kong Baptist University.

(20) Carroll, A. B. (1991) The pyramid of corporate social responsibility: toward the moral management of stakeholder organization, Business Horizon ,34(1), 39-48.

(21) Helg , A. (2007) Corporate Social Responsibility from a Nigerian perspective, Master Thesis, Vid Goteborgs Universitet.

(22)Sabeena,A. and Krishnamurthy, N.(2012) Corporate Social Responsibility In Accomplishment And Augmentation of Customer Loyalty - A Tactics of Indian Mobile Service Providers, Namex International Journal of Management Research ,146. 2, (2) , 145- 153.

(23) Inoue, Y. and Lee, S. (2011) Effects of different dimensions of corporate social responsibility on corporate financial performance in tourism-related industries, Tourism Management,32, 790 -804.

(24) Safi, A. and Ramay, M. (2013) Corporate Social Responsibility and Consumer Behavior: A Study from Pakistan, Information Management and Business Review, 5( 4) , 194-202.

(25) Ochoti, G. , Muathe, S. , Ronoh , P., Maronga , E. and Ochoti , F.( 2013 ) Corporate Social Responsibility, Client Satisfaction and Competitive advantage in retail banking institutions in Kenya, International Journal of Arts and Commerce, 2 (2), 161- 173.

(26) Swaen, V. (2002) Consumers' Perceptions, Evaluations And Reactions to CSR Activities, the 10th international conference of the Greening of Industry Network, June 23-26, Göteborg, Sweden.

(27) Alafi , K. and Al sufy, F. (2012) Corporate Social Responsibility Associated With Customer Satisfaction and Financial Performance: A Case Study with Housing Banks in Jordan, International Journal of Humanities and Social Science , 2 (15), 102- 115. 
(28) Selvarajh,T., Munusamy,J., Chelliah,S. and Pandian,S.(2012) An empirical study on corporate social responsibility in Malaysian aviation industry: A case study, African Journal of Business Management, 6 (8), 2919-2930.

(29) Hinz , O.(2004) Corporate social responsibility in the aviation industry, available at : www.docstoc.com/.../Corporate-Social-Responsibility...Airline-Industry, [Accessed on28 ${ }^{\text {th }}$ March2013] .

(30) Rigby, C. , Mueller, J. and Baker, A. (2011) The Integration of Maori Indigenous Culture into Corporate Social Responsibility Strategies at Air New Zealand, Journal of Marketing Development and Competitiveness , 5(6), 116-126.

(31) Singh, S.( 2010 ) Philanthropy to Corporate Social Responsibility: An Indian Perspective , Review of International Comparative Management , 11 (5), 990-1000.

(32) Anttila, T. and Kretzschmar, A. (2010) Application Of CSR Programs In The Airline Industry, Bachelor's Thesis, Saimaa University of Applied Sciences , Business Administration department .

(33) Atlantic Airways(2012) Corporate Social Responsibility in Atlantic Airways, available at : https $/ /$ www. atlantic. fo/da/om-os/investor-relations/csr.aspx, [ Accessed on $26^{\text {th }}$ April2013].

(34) Kemp, L.J. and Vink , J . (2012 ) Country Perspective CSR reporting: a review of the Pakistani aviation industry, South Asian Journal of Global Business Research,1(2) , 276-292.

(35) Saeednia, H. and Shafeiha, S. (2012) Investigation The Link Between Competitive Advantage \& Corporate Social Responsibility From Consumer's View, International Journal of Economics and Business Modeling , 3( 2), 177-182.

(36) Palazzi , M. and Starcher, G.(2006) Corporate Social Responsibility and Business Success, The European Baha'i Business Forum, available at : www. bahai library.com/?file=palazzi_starcher_social_responsibility. [ Accessed on $20^{\text {th }}$ June2013]

(37) Voet, S. (2010) The Impact of Stakeholder Influences on the Formation of CSR policy in the Airline Industry, BSc Thesis Business Administration.

(38) Air France and KLM Corporate social responsibility report 2007-2008, available at : www.klm.com/csr/en/images/CSR-report_0708-ENG_tcm696-305525.pdf [ Accessed on28 ${ }^{\text {th }}$ March 2013]

(39) Coles, T. , Fenclova,E. and Dinan, C. (2013) Tourism and corporate social responsibility: A critical review and research agenda, Tourism Management Perspectives , 6 ,122-141.

(40) Skouloudis, A. , Evangelinos, K . and Moraitis, S. (2012) Accountability and stakeholder engagement in the airport industry :An assessment of airports' CSR reports, Journal of Air Transport Management, 18 ,16-20.

(41) Cheng, J.H , Chen, F.Y. and Chang,Y. H. (2008) Airline relationship quality: An examination of Taiwanese passengers ,Tourism Management , 29, 487-499.

(42) Fenwick,T. (2010) Learning to practice Social Responsibility in small business: Challenges and Conflicts, Journal of Global Responsibility, 1(1), 149-169.

(43) Mandhachitara,R. and Poolthong,Y. (2011) A model of customer loyalty and corporate social responsibility, Journal of Services Marketing, 25(2), 122-133.

(44) Jan, M.T. , Abdullah, K. and Smail, M.H.( 2013) Antecedents of Loyalty in the Airline Industry of Malaysia: An Examination of Higher-Order Measurement Model , Proceedings of 3rd Asia-Pacific Business Research Conference 25 - 26 February 2013, Kuala Lumpur, Malaysia.

(45) Yuen, K. (2007) The Effect of Customer Trust on Customer Loyalty and Repurchase Intention: The Moderating Influence of Perceived CSR, Degree of Bachelor of Business Administration (Honours), Hong Kong Baptist University.

(46) Oliver, R. L.(1999), Whence Consumer Loyalty?, Journal of Marketing, 63(Special Issue), 33-44.

(47) McGregor, S.L.T. (2008) Consumer-citizen loyalty relationships in the context of corporate social responsibility, TMC Academic Journal,3 (1) , 25-38. 
(48) Salmones, M. , Crespo ,A. and Bosque, I. (2005) Influence of Corporate Social Responsibility on Loyalty and Valuation of Services , Journal of Business Ethics, 61 (4), 369-385.

(49) Boulstridge, E. and Carrigan , M. (2000) Do consumers really care about corporate responsibility: highlighting the attitude-behavior gap? , Journal of Communication Management, 4(4), 355-368.

(50) Leone ,R. and Rao ,V. (2006) Linking Brand Equity to Customer Equity. Journal of Service Research, $9(2), 125-138$.

(51) Liu,Y. and Zhou, X. (2009) Corporate Social Responsibility and Customer Loyalty: A Conceptual Framework, 6th International Conference on Service Systems and Service

Management, 794-798.

(52) Sen, S., Bhattacharya, C.B., and Korschun, D. (2006) The Role of Corporate Social Responsibility in Strengthening Multiple Stakeholder Relationships: A Field Experiment, Journal of the Academy of Marketing Science, 34(2), 158-166.

(53) Roofthooft, W.(2009) Customer equity: a creative tool for SMEs in the services industry: How small and medium enterprises can win the battle for innovation, services business, 4(1), 37-48.

(54) Hyun , S. (2009) Creating and Validating a Measure of Customer Equity in Hospitality Businesses: Linking Shareholder Value with Return on Marketing, Doctor of Philosophy in Hospitality and Tourism Management, Blacksburg, Virginia.

(55) Kyung , K., Kang, K., Dong, K., Jong K., and Suk, K. (2008) Brand equity in hospital marketing , Journal of Business Research 61( 1), 75-82.

(56) Litvin, S.W., Blose, J.E. and Laird, S.T. (2004) Tourist use of restaurant web-pages: is the internet a critical marketing tool? Journal of Vacation Marketing, 11 (2), 155-161.

(57) Servet, K. ( 2007) measuring the effectiveness of marketing effort in the convention industry : A customer equity approach, Appalachian State University, doctor of philosophy.

(58) Ruyter, K.,and Wetzels, M. (2000) Customer equity considerations in service recovery: acrossindustry perspective, International journal of service industry management 11(1), 91-108.

(59) Duman, T., and Mattila, A. (2005). The role of affective factors on perceived cruise vacation value. Tourism Management, 25(2), 311-323.

(60) Kwun, J. and Oh, H.(2004). Effects of brand, price, and risk on customers' value perceptions and behavioral intentions in the restaurant industry, Journal of Hospitality Leisure and Marketing 11 (1), 31-49.

(61) Smith, J.W.,( 1991), Thinking about brand equity and the analysis of customer transactions. In: Maltz, E., Editor, Managing brand equity: A conference summary, Marketing Science Institute, Cambridge, MA, $17-18$.

(62) Nick ,M. (2009) Designing a model for the valuation of tourism brands based on an empirical study, Master's Thesis, Università della Svizzera italiana, Faculty of Communication Sciences

(63) Konecnika ,M, and William ,W.(2007) Customer-based brand equity for a destination , Annals of Tourism Research, 34( 2), 400-421.

(64) Simoes, D. and Dibb, S. (2001).Rethinking the brand concept: new brand orientation, Corporate Communications, 6 ( 4), 217-24.

(65) Mackay, M. (2001) Evaluation of brand equity measures: further empirical results", Journal of Product and Brand Management, 10 ( 1), 38-51.

(66) Yoo, B. and Donthu, N. (2001) Developing and validating a multidimensional consumer-based brand equity scale, Journal of Business Research, 52(1) , 1-14.

(67) Keller, K.(2001) Building customer- based brand equity: A blueprint for creating strong brands ,Marketing science institute, working paper series ,(1),p.107. 
(68) Swarbrooke, J. (2002) The development and management of visitor attractions ,2nd ed., ButterworthHeinemann, Oxford, England.

(69) Chen, C. F. (2007) Experience quality, perceived value, satisfaction and behavioral Intentions for heritage tourists. Proceedings of the 13th Asia Pacific Management Conference, Melbourne, Australia, pp. 1130-1136.

(70) Chen, C. F., and Tsai, D. C. (2007) How destination image and evaluative factors affect behavioral intentions? Tourism Management, 28(4), 1115-1122.

(71) Murphy, E., Pritchard, M. and Smith, B.(2000) The destination product and its impact on traveler perceptions, Tourism Management 21 (1), 43-52.

(72)Oh, H. and Jeong, M. (2003). An extended process of value judgment, Hospitality Management 23, 343362.

(73) Petrick J.F. (2002) Experience use history as a segmentation tool to examine golf travellers' satisfaction, perceived value and repurchase intentions, Journal of Vacation Marketing 8 (4), 332-342.

(74) Delgado-Ballester, E. and Munuera-Alemán, J.L.(2005)Does Brand Trust Matter to Brand Equity? Journal of product \& Brand Management, 14(3), 187-196.

(75) Sweeney J.C. and Soutar, G. (2001) Consumer perceived value: the development of multiple item scale, Journal of Retailing 77 (2), 203-220.

(76) Caruana, A. (2002) Service loyalty: The effects of service quality and the mediating role of customer satisfaction. European Journal of Marketing, 36(7/8), 811-830.

(77) Richards, K.A. and Jones,E. (2008) Customer relationship management: Finding value drivers, Industrial Marketing Management, 37 , 120-130.

(78) Rust, R., Lemon, K., and Zeithaml, V. (2004) Return on marketing: using customer equity to focus marketing strategy. Journal of Marketing, 68, 109-27.

(79) Litvin, S.W., Blose, J.E. and Laird, S.T. (2004) Tourist use of restaurant web-pages: is the internet a critical marketing tool? Journal of Vacation Marketing, 11 (2), 155-161.

(80) Bolton, R. N., Lemon, K. N., and Verhoef, P. C. (2004) The theoretical underpinnings of customer asset management: A framework and propositions for future research, Journal of Academy of Marketing Science, 32(3), 271-292.

(81) Berger, P. D., Eechambadi, N., George, M., Lehmann, D. R., Rizley, R. and Venkatesan, R. (2006) From Customer Lifetime Value to Shareholder Value: Theory, Empirical Evidence, and Issues for Future Research. Journal of Service Research, 9(2), 156-167.

(82) Harrison-Walker, L. J. (2001) The measurement of word-of-mouth communication and an investigation of service quality and customer commitment as potential antecedents. Journal of Service Research, 4(1), 60-75.

(83) Palmer ,A. and S. Ponsonby, S. (2002) The social construction of new marketing paradigms: the influence of personal perspective, Journal of Marketing Management 18, 173-192.

(84) Smeeton, N.C. (1985) Early History of the Kappa Statistic. Biometrics, pp. 41- 79.

(85) Noypayak, W. ( 2009) Value Dimensions of Thailand as Perceived by U.K. Tourists, RU. Int. J. 3(1), 141-154.

(86) Given ,M. Lisa (2008) The Sage Encyclopedia of Qualitative Research Methods. Sage: Thousand Oaks, CA, 2,pp. 697-698.

(87) Wilmot, A.(2002) Designing sampling strategies for qualitative social research: with particular reference to the Office for National Statistics' Qualitative Respondent Register available at: www.ons.gov.uk/about/who-we.../designing-sampling-strategies-.pdf.[Accessed on 10th May, 2013]. 
(88) Polit, D. F and Hungler, B. P (1995) Nursing Research - Principles \& Methods ,5 th ed, Philadelphia, Lippincott Company.

(89) Polit, D. F. and Beck, C. T. (2003) In Nursing Research: Principles and Methods, 7th ed, Philadelphia, Lippincott Company .pp.413-444.

(90) Wilkins., T.(2006). Non-probability Sampling ,research methods knowledge base, Web center for social research method, available at: http://www.socialresearchmethods.net/kb/sampnon.php[Accessed on $23^{\text {th }}$ June 2013].

(91) Bartlett, J. Kotrlik , J. and Higgins, C.(2001) Organizational Research: Determining Appropriate Sample Size in Survey Research, Information Technology, Learning, and Performance Journal, 19(1), 4350.

(92)Winner ,L.(2003) Advanced Statistical Techniques, Available at: http://www.google.com.eg/url? sa=t\&rct=j\&q=\&esrc=s\&frm=1\&source=web\&cd=4\&ved=0CEAQFjAD\&ur l=http $\% 3 \mathrm{~A} \% 2 \mathrm{~F} \% 2 \mathrm{Fwww}$. stat.ufl.edu $\% 2 \mathrm{~F} \sim$ winner\% 2Fmar5621\%2Fmar5621.doc\&ei=kSUJU7rNGY in0AX -2ICAAQ\&usg=AFQjCNHe2SyhwxeE5pciUD8MMHyHUWZnBw\&bvm=bv.61725948,d.d2k [Accessed on $12^{\text {th }}$ June 2013]

(93) Bagozzi, R. P., Yi, Y., and Baumgartner, J. (1990) The level of effort required for behavior as a moderator of the attitude-behavior relation. European Journal of Social Psychology, 20(1), 45-59.

(94) Yang., Z. and Peterson. R.(2004 ) Customer Perceived Value, Satisfaction, and Loyalty: The Role of Switching Costs, Psychology \& Marketing, 21(10),799-822.

(95) Abbasi, M., Moezzi, H., Eyvazi, A.and Ranjbar ,V.(2012) Exploring of Relationship between Corporation Social Responsibility and Loyalty and Satisfaction Customer and the Facilitating Role of Advertising on It (Case study: SHIRAZIT Co.) International Journal of Academic Research in Business and Social Sciences , 2 ( 1), 460-468.

(96) Park,J., Robertson.R., and Wu, C.( 2005) Investigating the Effects of Airline Service Quality on Airline Image and Passengers' Future Behavioral Intentions: Findings from Australian international air passengers ,The journal of tourism studies, 16( 1)11-23.

(97) Maden, C., Arikan B, Telci, E.and Kantur, D. (2012) Linking corporate social responsibility to corporate reputation: a study on understanding behavioral consequences, Istanbul Kemerburgaz University, Istanbul, Social and Behavioral Sciences 58, $655-664$.

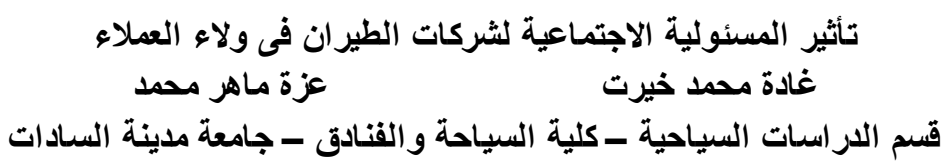

لقد تطور مفهوم المسئولية الاجتماعية بشكل ملحوظ في العقد الأخير ، حيث بدأت منظمات الأعمال الاهتمام بالمسئولية الاجتماعية بشكل أكثر

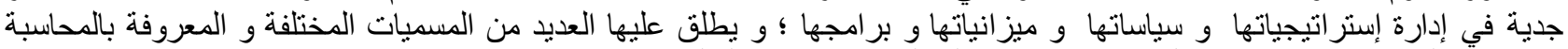

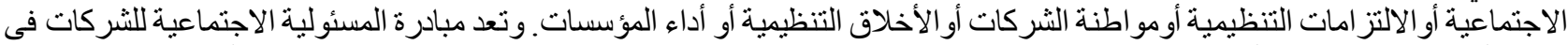

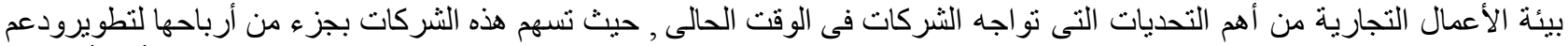

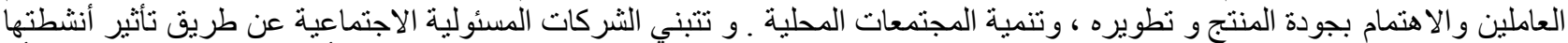

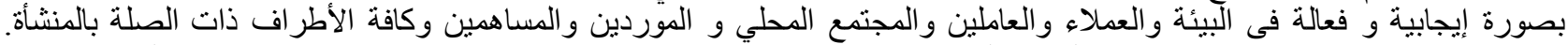

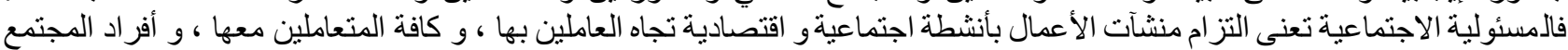

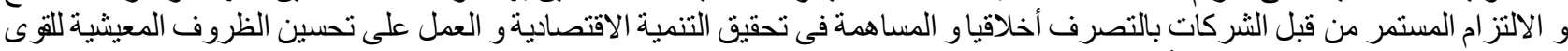

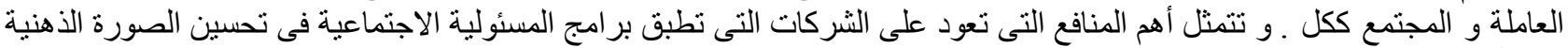

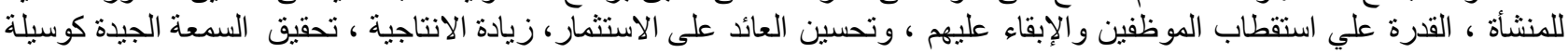

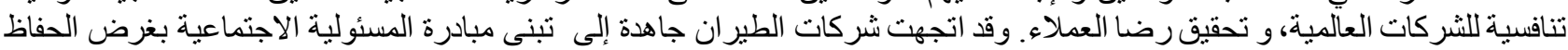

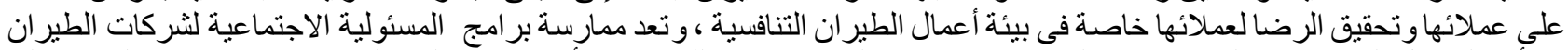

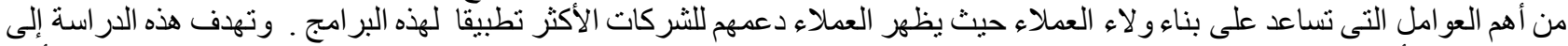

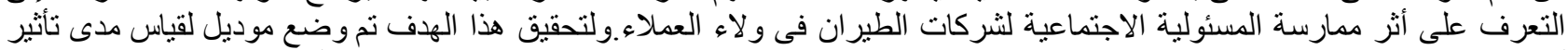

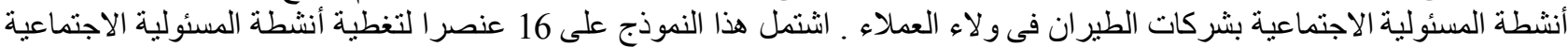

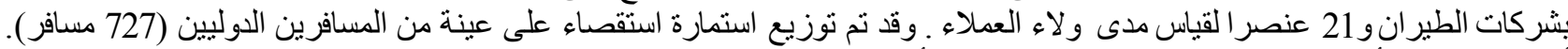
أظهرت النتائج أن هناك علاقة ذات دلالة إحصائية بين أنشطة المسئولية الاجنماعية بشركات الطير الطيران و و ولاء العملاء. 